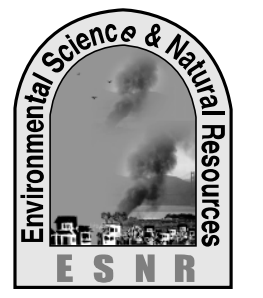

J. Environ. Sci. \& Natural Resources, 6(1): 221 - 226, 2013

ISSN 1999-7361

\title{
Performance of Phosphate Solubilizing Bacteria with Various Phosphorus Levels on Wheat in Pot Culture
}

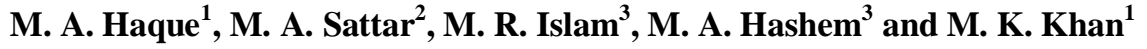 \\ ${ }^{1}$ Soil Microbiology Lab., Soil Science Division, ${ }^{2}$ Director General Office, Bangladesh Institute of Nuclear \\ Agriculture (BINA), Mymensingh, ${ }^{3}$ Department of Soil Science, BAU, Mymensingh
}

\begin{abstract}
A pot experiment was conducted to investigate the effect of different phosphate solubilizing bacteria (PSB) with various levels of inorganic phosphorus $(\mathrm{P})$ on the growth and yield of wheat with three soil at the Microbiology laboratory, Soil Science Division, Bangladesh Institute of Nuclear Agriculture (BINA), Mymensingh. Four levels of $\mathrm{P}$ fertilizer ( $\mathrm{P}_{0}$ : Without $\mathrm{P}$, $\mathrm{P}_{24}$ : $24 \mathrm{mg} \mathrm{P} \mathrm{kg}^{-1}$ soil, $\mathrm{P}_{36}: 36 \mathrm{mg} \mathrm{P} \mathrm{kg}^{-1}$ soil and $\mathrm{P}_{48}: 48 \mathrm{mg} \mathrm{P} \mathrm{kg}^{-1}$ soil) were assigned as main factors and six PSB inoculants with an uninoculant $\left(\mathrm{I}_{0}, \mathrm{MR} 1, \mathrm{IL} 1, \mathrm{IW} 1, \mathrm{IC} 2, \mathrm{RC} 1\right.$ and MW1) were assigned as sub factors in a factorial CRD. The soil used for the experiment belong to three Agroecological Zones (AEZs) such as AEZ 9 from the BAU farm, Mymensingh, AEZ 28 from the BADC farm, Madhupur, Tangail and AEZ 11 from the BINA substation farm, Ishurdi, Pabna. Eight kilogram soils were taken in each of the plastic pot. PSB were applied as broth inoculants with the wheat seeds (var. Shatabdi) before sowing. Irrespective of the PSB inoculants, $36 \mathrm{mg} \mathrm{P} \mathrm{kg}^{-1}$ soil gave the highest grain and straw yield of wheat pot ${ }^{-1}$ with Mymensingh and Mdhupur soil while $48 \mathrm{mg} \mathrm{P} \mathrm{kg}^{-1}$ soil showed the highest wheat yield pot ${ }^{-1}$ with Ishurdi soil. Among the PSB inoculants, MR1 showed the

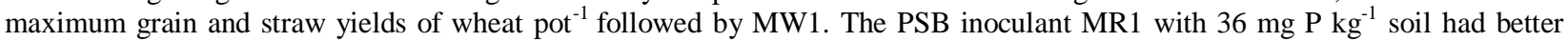
performance in terms of total $\mathrm{P}$ uptake and grain and straw yields of wheat.
\end{abstract}

Keywords: Phosphate solubilizing bacteria, P uptake, wheat yield

\section{Introduction}

Phosphorus is one of the limiting elements for crop production. It is essential for energy transfer, photosynthesis and other biochemical and genetic activities of plant (Armstrong 1988; Theodorou and Plaxton, 1993). Generally plants take up $\mathrm{P}$ as the primary $\left(\mathrm{H}_{2} \mathrm{PO}_{4}{ }^{-}\right)$and secondary orthophosphate $\left(\mathrm{HPO}_{4}{ }^{\prime}\right)$ ions. They are easily retained in most soils when added, and in many cases this retention is so high that the element becomes largely unavailable to the plants. Crop yield on $40 \%$ of the world's arable land is limited by $\mathrm{P}$ availability (Rodriguez and Fraga, 1999). So the availability of soil $\mathrm{P}$ in many countries of the world including Bangladesh is insufficient for higher crop productivity under intensive cultivation due to fixation of $\mathrm{P}$ with various soil complexes (Dattam et al. 2002). Therefore, the crop shows low use efficiency (10-25\%) of phosphate fertilizers. On the other hand continuous application of these fertilizers increased the total $\mathrm{P}$ in the soil over time, caused in large reserves of fixed $\mathrm{P}$ (Ali and Wakatsuki, 2008) which is unavailable to the plants. These forms of $\mathrm{P}$ are important aspects for $\mathrm{P}$ mineralization/mobilization through microbial mediated process to make available for the crop plants (Chen et al. 2005; Jeon et al., 2003). The transformation of mineral or organic $\mathrm{P}$ into soluble inorganic $\mathrm{P}$ is brought about by microbial action. Phosphate solubilizing bacteria (PSB) have potentiality to solubilize the unavailable $\mathrm{P}$ in rhizosphere soil and make it available to the crops (Afzal and Asghari, 2008; Hariprsad and Niranjana, 2009). Sundara et al. (2002) found that the application of PSB, Bacillus megaterium var. phosphaticum, increased the $\mathrm{P}$ availability in the soil. When used in conjunction with $\mathrm{P}$ fertilizers, PSB reduced the required $\mathrm{P}$ dosage by $25 \%$. Wheat is an important food grain of Bangladesh. Huge amount of $\mathrm{P}$ fertilizers are required every year to boost up production of this crop. It is needed to pay more attention to increase the production of wheat per unit area to feed the ever rising population and also ensure food security. Proper soil management through integrated use of efficient phosphatic biofertilizers along with inorganic sources of $\mathrm{P}$ fertilizers may increase the production of wheat crop in the country. Integrated use of chemical fertilizers and phosphatic biofertilizer may be a good option to increase the use efficiency of chemical P fertilizer by wheat crops. But information is scanty on use of efficient PSB strain as phosphatic biofertilizer for wheat cultivation in Bangladesh. Therefore, the present study was undertaken with the objective to evaluate the effects of different PSB inoculants on wheat in pot culture with diverse soils.

\section{Materials and methods}

The soils used for the pot experiment belongs to three Agroecological Zones (AEZs) namely: Old Brahmaputra Floodplain (AEZ 9) from the Bangladesh Agricultural University Farm (BAU farm), Mymensingh, Madhupur Tract (AEZ 28) from the Bangladesh Agriculture Development Corporation Seed Multiplication Farm (BADC farm), Madhupur, Tangail and High Ganges River Floodplain Soil (AEZ 11) from the BINA substation farm, Ishurdi, Pabna. The soils were collected at a depth of $0-15 \mathrm{~cm}$ from 
each site by means of spade. Eight kilogram processed soils were taken in each of the plastic pot $(23 \mathrm{~cm} \times 21 \mathrm{~m})$. The experiment was conducted in a factorial CRD. Four levels of $\mathrm{P}$ fertilizer $\left(\mathrm{P}_{0}\right.$ : Without $\mathrm{P}, \mathrm{P}_{24}: 24 \mathrm{mg} \mathrm{P} \mathrm{kg}^{-1}$ soil, $\mathrm{P}_{36}: 36 \mathrm{mg} \mathrm{P} \mathrm{kg}^{-1}$ soil and $\mathrm{P}_{48}: 48 \mathrm{mg} \mathrm{P} \mathrm{kg}^{-1}$ soil) were assigned as main factors and six PSB inoculants with an uninoculant control $\left(\mathrm{I}_{0}\right.$ : Uninoculated control, $\mathrm{I}_{1}$ : PSB inoculants MR1, $\mathrm{I}_{2}$ : PSB inoculant IL1, $\mathrm{I}_{3}$ : PSB inoculant IW1, $\mathrm{I}_{4}$ : PSB inoculant $\mathrm{IC} 2, \mathrm{I}_{5}$ : PSB inoculant $\mathrm{RC} 1$ and $\mathrm{I}_{6}$ : PSB inoculant MW1) were assigned as sub factor treatments for each soil. Each treatment was replicated thrice. $\mathrm{P}$ fertilizer was applied as per treatment plan from triple super phosphate (TSP). Potassium was applied @ $160 \mathrm{mg} \mathrm{K} \mathrm{kg}^{-1}$ soil from muriate of potash (MoP) as basal in each pot. Nitrogen fertilizer@240 mg N kg-1 soil was applied as urea in three equal splits in all the pots. Wheat seeds (var. Shatabdi) were soaked (except uninoculated control pots) separately with the culture broth of each PSB inoculant containing $10^{12}$ cells $\mathrm{mL}^{-}$

${ }^{1}$ broth for $30 \mathrm{~min}$ before sowing. Inoculated and uninoculated wheat seeds were sown separately into the pots. After germination of wheat seeds, only five plants were kept for normal growth in each pot. The wheat plants were harvested when attained at full maturity and yields were recorded in $\mathrm{g} \mathrm{pot}^{-1}$. The initial soils were analyzed (Table 1) for texture, organic carbon content, cation exchange capacity, total nitrogen, available phosphorus, total phosphorus, exchangeable potassium following standard methods (Black, 1965; Jackson,1967; Page et al., 1982; Olsen et al., 1954; Bray and Kurtz, 1945; Murphy and Riley, 1962). Grain and straw samples were digested following standard method and phosphorus content in the digested samples was determined colorimetrically by vanado-molybdo yellow colour method (Yoshida, 1976). After determination of $P$ content in grain and straw samples of wheat, $\mathrm{P}$ uptakes were calculated using the value of $\mathrm{P}$ contents (Jackson, 1967). Analysis of variance was performed in factorial CRD followed by F-test to examine whether the treatment effects were significant (Gomez and Gomez, 1984) using MSTATC computer pakage program.

Table 1. Physical and chemical characteristics of initial soils

\begin{tabular}{|c|c|c|c|}
\hline Characteristics & $\begin{array}{c}\text { BAU, farm } \\
\text { Mymensingh }\end{array}$ & $\begin{array}{l}\text { BADC farm, } \\
\text { Madhupur }\end{array}$ & $\begin{array}{l}\text { BINA substation, } \\
\text { Ishurdi }\end{array}$ \\
\hline Textural class & Loam & Sandy clay loam & Loam \\
\hline Cation exchange capacity $\left(\mathrm{cmol} \mathrm{kg}^{-1}\right)$ & 12.4 & 14.8 & 13.6 \\
\hline Soil pH & 6.75 & 4.7 & 7.5 \\
\hline Organic carbon $(\%)$ & 0.84 & 0.62 & 0.48 \\
\hline Total N (\%) & 0.084 & 0.056 & 0.042 \\
\hline Available $\mathrm{P}\left(\mathrm{mg} \mathrm{kg}^{-1}\right.$ soil $)$ & 3.48 & 10.5 & 18.33 \\
\hline Total P (mg kg-1 soil) & 755.6 & 817.0 & 1454.5 \\
\hline Exchangeable $\mathrm{K}$ ( $\mathrm{cmol} \mathrm{kg}^{-1}$ soil $)$ & 0.078 & 0.242 & 0.237 \\
\hline
\end{tabular}

\section{Results and Discussion}

\section{Effects on grain and straw yields of wheat}

PSB inoculants with various levels of $\mathrm{P}$ fertilizer significantly influenced the grain and straw yields of wheat in pot culture with Mymensingh, Madhupur and Ishurdi soils (Table 2 and Fig. 1). Irrespective of the PSB inoculants, $36 \mathrm{mg} \mathrm{P} \mathrm{kg}^{-1}$ soil gave maximum grain yields (10.6 $\mathrm{g}$ and $8.4 \mathrm{~g} \mathrm{pot}^{-1}$ ) of wheat with Mymensingh and Madhupur soils, respectively while $48 \mathrm{mg} \mathrm{P} \mathrm{kg}$ soil showed maximum grain yield (26.0 $\mathrm{g} \mathrm{pot}^{-1}$ ) with Ishurdi soil. But $36 \mathrm{mg} \mathrm{P} \mathrm{kg}^{-1}$ soil and $48 \mathrm{mg} \mathrm{P} \mathrm{kg}^{-1}$ soil produced statistically identical grain yields with all soils. Similar results were observed in case of straw yields with all the soils. Irrespective of the $\mathrm{P}$ levels, the highest grain yields (9.6, 7.5 and $23.5 \mathrm{~g} \mathrm{pot}^{-1}$ ) were recorded with the PSB inoculant MR1 with Mymensingh, Madhupur and Ishurdi soils, respectively followed by the inoculant MW1 with Mymensingh (9.3 $\mathrm{g} \mathrm{pot}^{-1}$ ) and Madhupur (6.9 $\mathrm{g} \mathrm{pot}^{-1}$ ) soils. PSB inoculants RC1showed the highest yield with Ishurdi soil $\left(22.4 \mathrm{~g} \mathrm{pot}^{-1}\right)$. But the inoculants MR1 and MW1 produced statistically identical grain yields of wheat pot $^{-1}$ with Mymensingh and Madhupur soils while the inoculants MR1 produced significantly different grain yield from the inoculants RC1 and MW1 with Ishurdi soil. Minimum grain yields were recorded in uninoculant $\left(\mathrm{I}_{0}\right)$ with all soils which ranged from 5.0-18.7 $\mathrm{g} \mathrm{pot}^{-1}$. Similar trends were also observed in case of straw yields of wheat as regard to the PSB inoculants (Table 2 ). Inoculation by PSB with inorganic $P$ increased the grain and straw yields of wheat and other crops were reported by many workers (Chaykovskaya et al., 2001; Tomar et al., 1996). These findings were almost similar to those of Afzal et al. (2005) who found that phosphate solubilizing microorganisms (PSM) alone or along with other combinations showed profound effect on grain and biological yield of wheat. In the present study grain and straw yields of wheat were also significantly influenced with the interaction between P levels and PSB inoculants with 
all soils (Fig.1). Maximum grain yields (12.9 and 9.5 g pot $^{-1}$ ) were recorded by the treatment $\mathrm{P}_{36} \times \mathrm{MR} 1$ with Mymensingh and Madhupur soils, respectively followed by the treatment $\mathrm{P}_{36} \times \mathrm{MW} 1$. With Ishurdi soil, the treatment $\mathrm{P}_{48} \times \mathrm{MR} 1$ produced the maximum grain yield $\left(28.4 \mathrm{~g} \mathrm{pot}^{-1}\right)$. This was followed by the treatment $\mathrm{P}_{48} \times \mathrm{IL1}\left(27.7 \mathrm{~g} \mathrm{pot}^{-1}\right)$ but they gave statistically identical grain yield of wheat with Ishurdi soil. The lowest grain yields of wheat were recorded with the control treatment $\mathrm{P}_{0} \mathrm{I}_{0}\left(2.4-9.5 \mathrm{~g} \mathrm{pot}^{-1}\right)$ with all soils. Similar results were also observed in case of straw yields of wheat (Fig. 2). Saad and Hammad (1998) reported that the greatest grain yield of wheat was found with inoculation of bacteria and application of calcium superphosphate. These results were also in conformity with the findings of Dwivedi et al. (2004) who reported that pre sowing inoculation of wheat seeds with phosphate solubilizing microorganisms led to a yield increase over noninoculated treatments.

Table 2. Effects of PSB inoculants with different levels of $P$ on grain and straw yields of wheat with three soils in pot culture

\begin{tabular}{|c|c|c|c|c|c|c|}
\hline \multirow[b]{2}{*}{ Factors } & \multicolumn{2}{|c|}{ Mymensingh } & \multicolumn{2}{|c|}{ Madhupur } & \multicolumn{2}{|c|}{ Ishurdi } \\
\hline & $\begin{array}{c}\text { Grain } \\
\left(\mathrm{g} \mathrm{pot}^{-1}\right)\end{array}$ & $\begin{array}{c}\text { Straw } \\
\left(\mathrm{g} \mathrm{pot}^{-1}\right)\end{array}$ & $\begin{array}{c}\text { Grain } \\
\left(\text { g pot }^{-1}\right)\end{array}$ & $\begin{array}{c}\text { Straw } \\
\left(\mathrm{g} \mathrm{pot}^{-1}\right)\end{array}$ & $\begin{array}{c}\text { Grain } \\
\left(\text { g pot }^{-1}\right)\end{array}$ & $\begin{array}{c}\text { Straw } \\
\left(\mathrm{g} \mathrm{pot}^{-1}\right)\end{array}$ \\
\hline$P$ levels(mgPkg ${ }^{-1}$ soil $) \mathrm{P}_{0}$ & $3.1 \mathrm{c}$ & $5.6 \mathrm{~b}$ & $3.2 \mathrm{c}$ & $6.3 \mathrm{~b}$ & $12.5 \mathrm{c}$ & $16.0 \mathrm{c}$ \\
\hline $\mathrm{P}_{24}$ & $9.6 \mathrm{~b}$ & $10.8 \mathrm{a}$ & $6.2 \mathrm{~b}$ & $8.0 \mathrm{~b}$ & $19.6 \mathrm{~b}$ & $25.0 \mathrm{~b}$ \\
\hline $\mathrm{P}_{36}$ & $10.6 \mathrm{a}$ & $12.2 \mathrm{a}$ & $8.4 \mathrm{a}$ & $10.2 \mathrm{a}$ & $25.8 \mathrm{a}$ & $32.9 \mathrm{a}$ \\
\hline $\mathrm{P}_{48}$ & $10.4 \mathrm{a}$ & $12.0 \mathrm{a}$ & $7.8 \mathrm{a}$ & $10.7 \mathrm{a}$ & $26.0 \mathrm{a}$ & $33.2 \mathrm{a}$ \\
\hline $\mathrm{SE}( \pm)$ & 0.08 & 0.44 & 0.21 & 0.36 & 0.21 & 0.80 \\
\hline PSB inoculants & & & & & & \\
\hline $\mathrm{I}_{0}$ & $7.8 \mathrm{~d}$ & $8.9 \mathrm{c}$ & $5.0 \mathrm{c}$ & $7.4 \mathrm{~b}$ & $18.7 \mathrm{e}$ & $23.9 \mathrm{e}$ \\
\hline MR1 & $9.6 \mathrm{a}$ & $11.6 \mathrm{a}$ & $7.5 \mathrm{a}$ & $9.7 \mathrm{a}$ & $23.5 \mathrm{a}$ & $30.0 \mathrm{a}$ \\
\hline IL1 & $7.9 \mathrm{~cd}$ & $9.6 \mathrm{c}$ & $6.5 \mathrm{ab}$ & $8.8 \mathrm{ab}$ & $21.6 b c$ & $27.5 b c$ \\
\hline IW1 & $8.0 \mathrm{~cd}$ & $9.6 \mathrm{c}$ & $6.2 b$ & $8.5 \mathrm{ab}$ & $21.0 \mathrm{~cd}$ & $26.8 \mathrm{~cd}$ \\
\hline $\mathrm{IC} 2$ & $7.8 \mathrm{~cd}$ & $9.4 \mathrm{c}$ & $6.3 \mathrm{~b}$ & $8.6 \mathrm{ab}$ & $19.3 \mathrm{e}$ & $24.7 \mathrm{e}$ \\
\hline $\mathrm{RC} 1$ & $8.6 \mathrm{bc}$ & $11.1 \mathrm{ab}$ & $6.4 \mathrm{ab}$ & $9.2 \mathrm{a}$ & $22.4 \mathrm{~b}$ & $28.6 \mathrm{~b}$ \\
\hline MW1 & $9.3 \mathrm{ab}$ & $10.7 \mathrm{~b}$ & $6.9 \mathrm{ab}$ & $9.4 \mathrm{a}$ & $20.3 d$ & $25.9 \mathrm{~d}$ \\
\hline $\mathrm{SE}( \pm)$ & 0.20 & 0.18 & 0.27 & 0.39 & 0.29 & 0.25 \\
\hline $\mathrm{CV}(\%)$ & 6.35 & 6.17 & 14.74 & 15.49 & 4.08 & 3.98 \\
\hline
\end{tabular}

SE: Standard error

In a column figures having common letter(s) do not differ significantly at $5 \%$ level of significance.

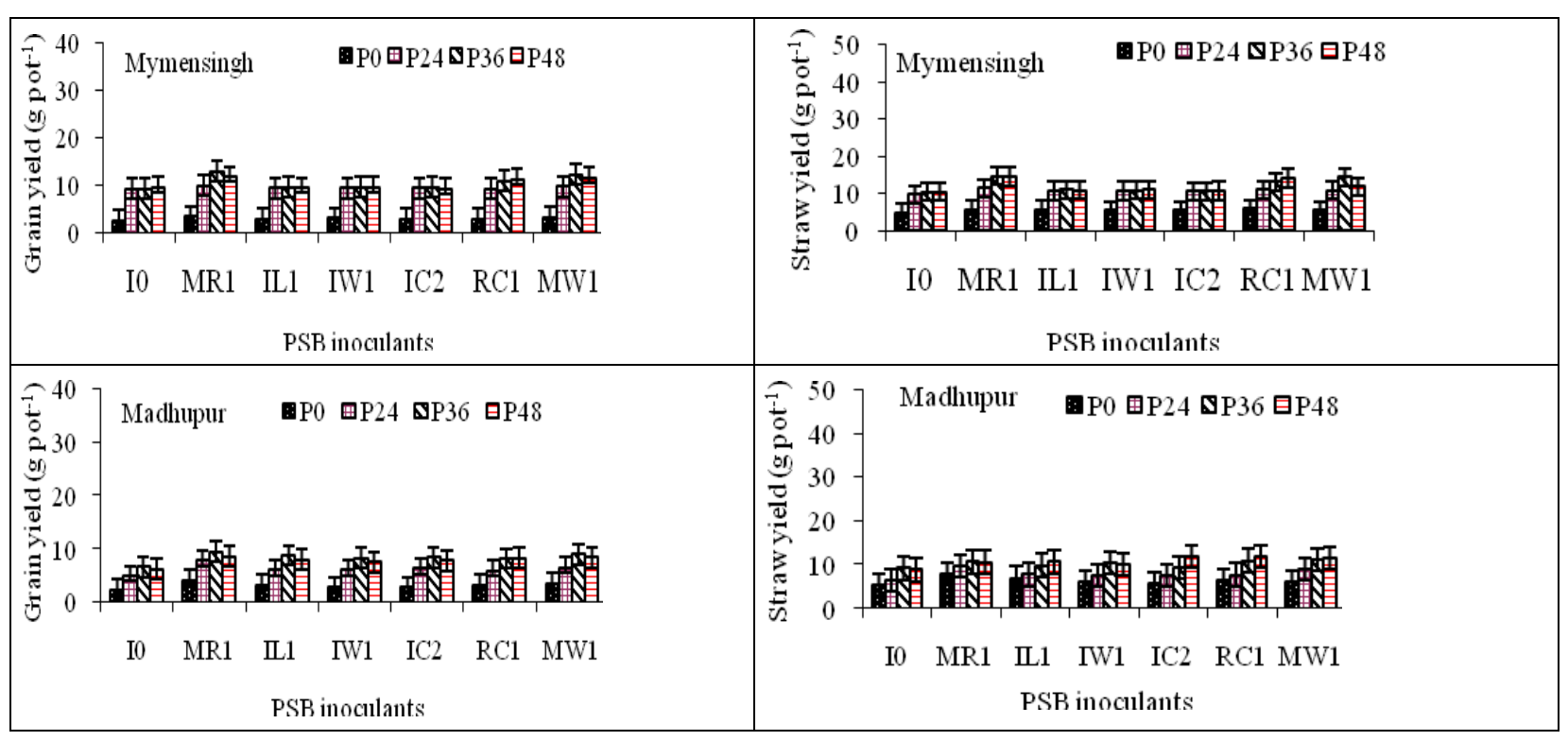




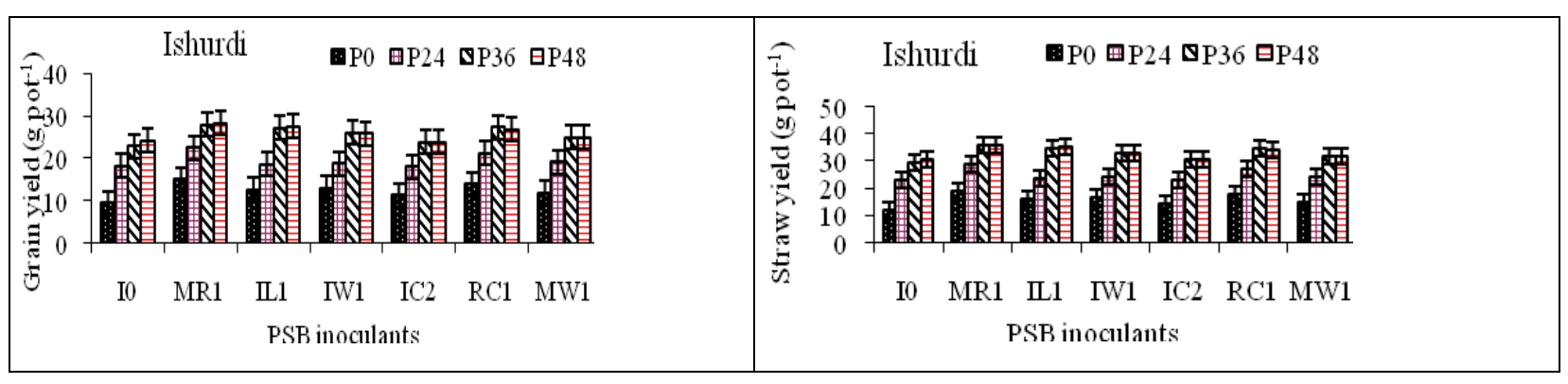

Fig. 1. Interaction effects of PSB inoculants with various P levels on grain and straw yields of wheat with three soils in pot culture (Vertical bars indicate standard errors)

\section{Effects on P uptake by wheat}

Total P uptake by wheat was significantly influenced by the different treatments with three soils (Table 3 and Fig. 2). Irrespective of the PSB inoculants, $36 \mathrm{mg}$ $\mathrm{P} \mathrm{kg}^{-1}$ soil gave maximum total $\mathrm{P}$ uptake of wheat and this was followed by the treatment $48 \mathrm{mg} \mathrm{P} \mathrm{kg}^{-1}$ soil with all soils. Without $P$ gave the lowest $P$ uptake of wheat with all soils. Irrespective of P levels, the PSB inoculant MR1 showed significantly higher total $\mathrm{P}$ uptakes of wheat (48.3, 40.7 and $125.2 \mathrm{mg} \mathrm{P}$ pot $^{-1}$ with Mymensingh, Madhupur and Ishurdi soils, respectively) followed by the inoculant MW1 with all soils (Table 3). Uninoclant $\left(\mathrm{I}_{0}\right)$ showed the lowest $\mathrm{P}$ uptakes with all soils. Interactions between P levels and PSB inoculants also significantly influenced the total P uptakes of wheat with three soils (Fig. 2). Maximum total $\mathrm{P}$ uptakes (68.5, 52.8 and $156.2 \mathrm{mg} \mathrm{P}$ pot $^{-1}$ ) of wheat were observed by the treatment $\mathrm{P}_{36} \times \mathrm{MR} 1$ with Mymensingh, Madhupur and Ishurdi soils, respectively. The second highest total $\mathrm{P}$ uptakes were found by the treatment $\mathrm{P}_{48} \times \mathrm{MR} 1$ with
Mymensingh (60.1 mg P pot ${ }^{-1}$ ), Madhupur (47.3 mg P pot $^{-1}$ ) and Ishurdi (152 mg P pot $\left.{ }^{-1}\right)$ soils. The results indicated that application of PSB inoculants with inorganic $\mathrm{P}$ showed greater $\mathrm{P}$ uptake of wheat with three soils in pot culture. Evidences have been found on the favourable effect of PSB in providing plant nutrient to cereals and supplementing the expensive inorganic fertilizers. The microbial inoculants in combination with inorganic fertilizer have augmented the yields and nutrients uptake by several crops (Linu et al., 2009; Kaprekar, 2003; Yadav et al., 2011). Gera et al. (2005) reported that inoculation of PSB transconjugants as well as parent increased the plant biomass production and $\mathrm{P}$ uptake in pot culture. $\mathrm{P}$ uptake improved by pearl millet with soil amendments with rock phosphate and seed inoculation with PSB (Kundu et al. 2006). PSB inoculated treatment showed higher $\mathrm{P}$ uptake by wheat with all soils in the present study and these are well accordance with those findings.

Table 3. Effects of PSB inoculants with different levels of $\mathrm{P}$ fertilizer on total $\mathrm{P}$ uptake $\left(\mathrm{mg} \mathrm{P}\right.$ pot $\left.^{-1}\right)$ by wheat with three soils in pot culture

\begin{tabular}{|l|c|c|c|}
\hline Factors & Mymensingh & Madhupur & Ishurdi \\
\hline P levels (mg P kg ${ }^{-1}$ soil) $\mathrm{P}_{0}$ & $14.4 \mathrm{~d}$ & $16.4 \mathrm{c}$ & $57.7 \mathrm{c}$ \\
$\mathrm{P}_{24}$ & $42.2 \mathrm{c}$ & $29.9 .0 \mathrm{~b}$ & $96.2 \mathrm{~b}$ \\
$\mathrm{P}_{36}$ & $50.8 \mathrm{a}$ & $43.0 \mathrm{a}$ & $133.4 \mathrm{a}$ \\
$\mathrm{P}_{48}$ & $46.9 \mathrm{~b}$ & $40.1 \mathrm{a}$ & $129.2 \mathrm{a}$ \\
\hline SE $( \pm)$ & 0.46 & 0.55 & 2.1 \\
\hline PSB inoculants & & & \\
$\mathrm{I}_{0}$ & $32.1 \mathrm{~cd}$ & $24.4 \mathrm{~d}$ & $88.7 \mathrm{e}$ \\
MR1 & $48.3 \mathrm{a}$ & $40.7 \mathrm{a}$ & $125.2 \mathrm{a}$ \\
IL1 & $35.7 \mathrm{bc}$ & $31.4 \mathrm{bc}$ & $102.1 \mathrm{~cd}$ \\
IW1 & $35.1 \mathrm{bc}$ & $30.7 \mathrm{c}$ & $99.5 \mathrm{~d}$ \\
IC2 & $35.5 \mathrm{bc}$ & $31.3 \mathrm{bc}$ & $97.3 \mathrm{~d}$ \\
RC1 & $38.7 \mathrm{~b}$ & $31.2 \mathrm{bc}$ & $109.9 \mathrm{~b}$ \\
MW1 & $44.9 \mathrm{a}$ & $36.6 \mathrm{ab}$ & $106.1 \mathrm{bc}$ \\
\hline SE $( \pm)$ & 0.59 & 1.35 & 1.22 \\
\hline CV $(\%)$ & 5.29 & 14.45 & 4.08 \\
\hline
\end{tabular}

SE: Standard error

In a column figures having common letter(s) do not differ significantly at $5 \%$ level of significance. 


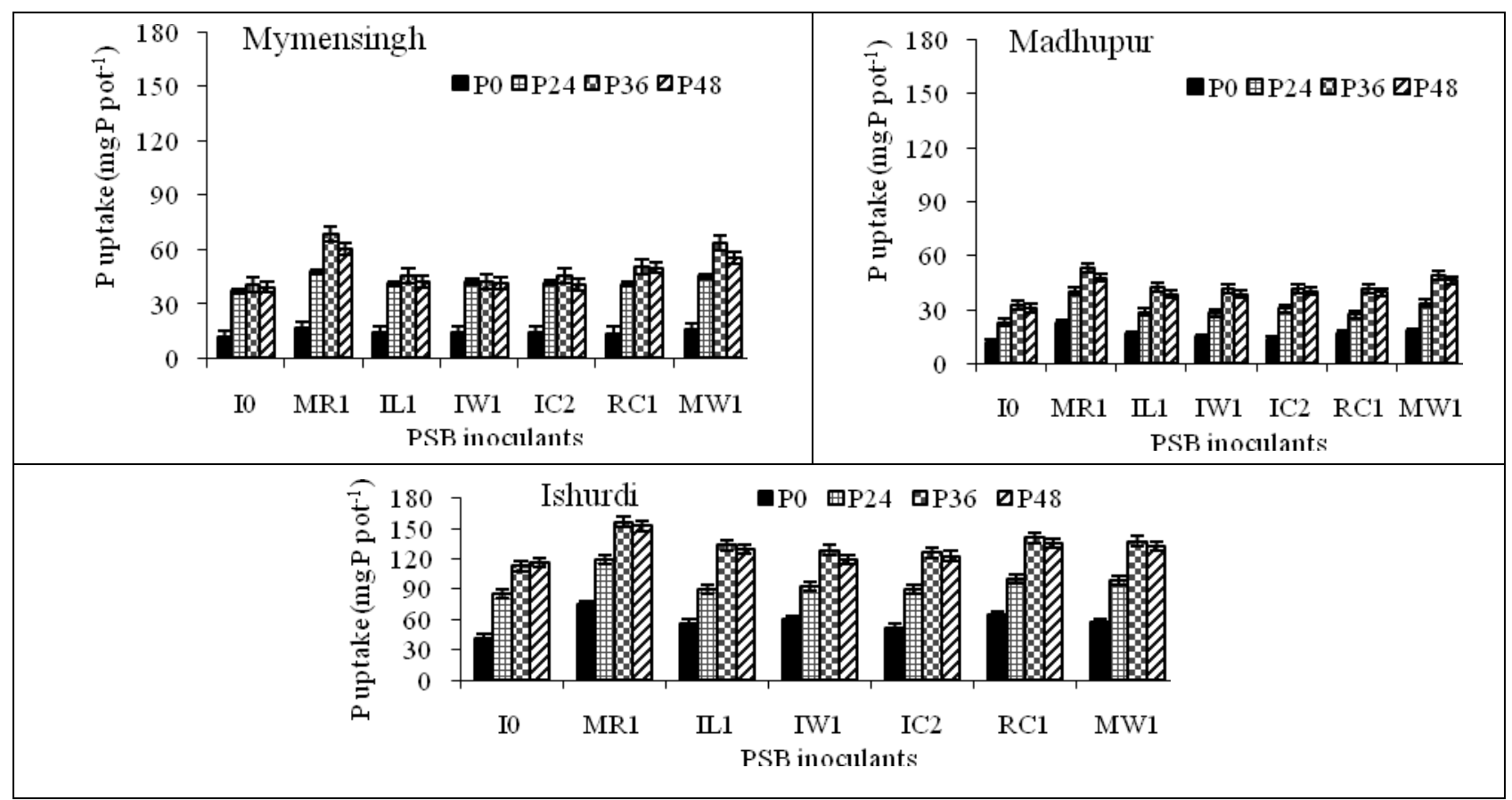

Fig. 2. Interaction effects of PSB inoculants with various $P$ levels on total $P$ uptake by wheat with three soils in pot culture (Vertical bars indicate standard errors)

\section{Conclusions}

From the results it can be concluded that among the PSB inoculants either MR1 or MW1 with reduced rate of $\mathrm{P}$ fertilizer showed better performance in wheat yield than $\mathrm{P}$ fertilizer alone. These two promising PSB inoculants can be used as potential phosphatic biofertilizer to save the inorganic $\mathrm{P}$ fertilizer for wheat cultivation in Bangladesh.

\section{References}

Afzal, A. and Asghari, B. 2008. Rhizobium and phosphate solubilising bacteria improve the yield and phosphorus uptake in wheat (Triticum aestivum L.). Int. J. Agric. Biol., 10: 85-88.

Ali, M. M. and Wakatsuki, T. 2008. Phosphorus stocks of paddy soils in different physiographic units and its changes between 1967 and 1995 in Bangladesh. Bangladesh J. Environ. Sci., 15: 59-64.

Armstrong, D. L. 1988. Role of phosphorus in plants: In: Armstrong, D. L. (ed.), Better Crops with Plant Food., Potash and phosphate Institute, Atlanta, USA, pp 4-5.

Black, C. A. 1965. Methods of Soil Analysis. Part I and II. Am. Soc. Agron. Inc. Pub. Madison, Wisconsin, U.S.A.
Bray, R. H. and Kurtz, L. T. 1945. Determination of total, organic and available forms of phosphorus in soils. Soil Sci., 59:39-45.

Chaykovskaya, L. A.; Patyka, V. P. and Melnychuk, T. M. 2001. Phosphorus mobilizing microorganisms and their influence on the productivity of plants. In: W.J. Horst (ed.), Plant Nutrition- Food Security and Sustainability of Agroecosystems. pp. 668-669.

Chen, Y. P.; Rekha, P. D.; Arun, A. B.; Shen, F. T.; Lai, W. A. and Young, C. C. 2005. Phosphate solubilizing bacteria from sub tropical soil and their tricalcium phosphate solubilization abilities. Appl. Soil Ecol., 34:3

Dattam, S.; Banik, S. and Dhiman, K. R. 2002. Efficacy of a phosphobacterium (Bacillus firmus) in combination with phosphates and organics on rice productivity in acid soils. Paper presented at the $17^{\text {th }}$ WCSS, Symp. no. 16, Paper no.7, 14-21 August 2002, Thailand.

Dwivedi, B. S.; Singh, V. K. and Dwivedi, V. 2004. Application of phosphate rock, with or without Aspergillus awamori inoculation, to meet phosphorus demands of rice-wheat systems in the Indo-Gangetic Plains of India. Austr. J. Exptl. Agric., 44: 1041-1050.

Gera, R.; Bhatia, A.; Sharma, P. K. and Kundu, B.S.. 2005b. Establishement of genetically marked 
phosphate solubilizing bacteria in the rhizosphere of pearl millet (Pennisetum glaucum). Biofert. News Lett., 13: 24-28.

Gomez, K. A. and Gomez, A. A. 1984. Statistical Procedures for Agricultural Research. John Wiley and Sons, New York.

Hariprasad, P. and Niranjana, S. R. 2009. Isolation and characterization of phosphate solubilizing rhizobacteria to improve plant health of tomato. Plant Soil, 316: 13-24.

Jackson. M. L. 1967. Soil Chemical Analysis. Prentice Hall of India (Private) Ltd. New Delhi, India.

Jeon, J. S.; Lee, S.; Kim, H. Y.; Ahn, T. S. and Song, H. 2003. Plant growth promotion in soil by some inoculated microorganisms. The J. Microbiol. Soc. Korea., 41: 271-276.

Kaprekar, N.; Sarode, D. S. and Patil, A. 2003. Yield, nutrient uptake and economics of gram (Cicer arietinum) as influenced by $\mathrm{P}$ and $\mathrm{S}$ levels and PSB inoculation under irrigated conditions. Legume Res., 26: 125-127.

Kundu, B. S.; Nandal, S.; Tiwari, M. and Tomar, M. 2006. Establishment and influence of phosphate solubilizing bacteria on pearl millet. Indian J. Pl. Physiol., 11(2): 201-205.

Linu, M. S.; Stephen, J. and Jisha, M. S. 2009. Phosphate solubilizing Gluconacetobacter sp., Burkholderia sp. and their potential interaction with cowpea (Vigna unguiculata (L.) Walp.). Int. J. Agric. Res., 4: 79-87.

Murphy, J. and Riley, J. P. 1962. A modified single solution method for the determination of phosphate in natural waters. Anal. Chem. Acta., 27: 21-36.

Olsen, S.R.; Cole, C.V.; Watanabe, F. S. and Dean, L.A. 1954. Estimation of available phosphorus in soils by extraction with sodium bicarbonate. U.S. Department of Agriculture Circular 939.
Page, A. L.; Miller, R. H. and Keeney, D. R. (ed.). 1982. Methods of Soil Analysis. Part 2, Chemical and Microbiological Properties. $2^{\text {nd }}$ Ed. Amer. Soc. Agron. Inc., Madison, Wisconsin, U.S.A. 403430 .

Rodríguez H. and Fraga, R. 1999. Phosphate solubilizing bacteria and their role in plant growth promotion. Biotechnol. Adv., 17: 319-339.

Saad, O.A.O. and Hammad, A. M. M. 1998. Fertilizing wheat plants with rock phosphate combined with phosphate dissolving bacteria and VAmycorrhizae as alternate for $\mathrm{Ca}-$ superphosphate. Ann. Agric. Sci., 43: 445-60.

Sundara, B.; Natarajan, V. and Hari, K. 2002. Influence of phosphorus solubilizing bacteria on the change in soil available phosphorus and sugarcane and sugar yields. Field Crop Res., 77: 43-49.

Tandon, H. L. S. 1987. Phosphorus Research and Agricultural Production in India. Fertilizer Development and Consultation organization, New Delhi. pp. 160.

Theodorou, M. E. and Plaxton, W. C. 1993. Metabolic adaptations of plant respiration to nutritional phosphate deprivation. Pl. Physiol., 101: 339344.

Tomar, S. S.; Khankar, U. R. and Sharma, S. K. 2002. Availability of phosphorus to black gram as influenced by phosphate solubilizing bacteria and phosphate levels. JNKVV, Res. J., 36 (1-2): 98-100.

Yadav, J.; Yadav, S. and Singh, S. G. 2011. Plant growth promotion in wheat crop under environmental condition by PSB as bio-fertilizer. Res. J. Agril. Sci., 2(1): 76-78.

Yoshida, R. K. 1976. Studies on organic phosphorus compounds in soil, isolation of inositol. Soil Sci., 60: 81-89. 